medRxiv preprint doi: https://doi.org/10.1101/2021.04.13.21254467; this version posted April 15, 2021. The copyright holder for this preprint (which was not certified by peer review) is the author/funder, who has granted medRxiv a license to display the preprint in perpetuity.

All rights reserved. No reuse allowed without permission.

\title{
Ornithine Decarboxylase (ODC1) gene variant (rs2302615) is associated with gastric cancer independently of Helicobacter pylori CagA serostatus
}

\author{
Running title: \\ Ornithine decarboxylase variants and gastric cancer risk
}

\begin{abstract}
Anna K Miller¹, Gloria Tavera*2, Ricardo L Dominguez³ ${ }^{\star 2}$ Constanza Camargo4, Tim Waterboer ${ }^{5}$, Keith T Wilson ${ }^{6,7}$, Scott M Williams ${ }^{\star 1,2}$, Douglas R Morgan ${ }^{\star 8}$
\end{abstract}

1. Department of Genetics and Genome Sciences, Case Western Reserve University, Cleveland, $\mathrm{OH}$

2. Department of Population and Quantitative Health Sciences, Case Western Reserve University, Cleveland, $\mathrm{OH}$

3. Hospital de Occidente, Ministry of Health, Santa Rosa de Copan, Copan, Honduras.

4. Division of Cancer Epidemiology and Genetics, National Cancer Institute, Rockville, MD.

5. Infections and Cancer Epidemiology, German Cancer Research Center (DKFZ), Germany.

6. Vanderbilt University Medical Center, Division of Gastroenterology, Hepatology, and Nutrition.

7. Veterans Affairs Tennessee Valley Healthcare System, Nashville, TN

8. UAB Division of Gastroenterology and Hepatology, The University of Alabama at

Birmingham (UAB).

*These authors contributed equally to this work

\section{Corresponding authors}

Douglas R. Morgan, MD MPH

Professor of Medicine and Epidemiology

Director, UAB Division of Gastroenterology and Hepatology

The University of Alabama at Birmingham

drmorgan @uabmc.edu

205-934-0883

Scott M. Williams, PhD

Professor of Population and Quantitative Sciences

Case Western Reserve University

smw154 @case.edu

216-368-5659

Keywords: Ornithine decarboxylase, gastric cancer, H. pylori, CagA, SNP, Central America, Honduras.

\section{Competing Interests}

The authors declare that they have no competing interests.

\section{Funding}

This study was funded in part by the U.S. National Cancer Institute (P01CA028842 (DRM, KTW, SMW), R01CA190612 (DRM, KTW), K07 CA125588 (DRM), PAR-15-155 (DRM), P30CA068485 (DRM, KTW), P01CA116087 (KTW), Veterans Affairs Merit 
Review grant I01CX002171 (KTW), Department of Defense grant W81XWH-18-1-0301 (KTW), and National Library of Medicine 1R01LM010098 (SMW).

The funders of the study had no role in study design, data collection, data analysis, data interpretation, or writing of the manuscript. SBR, RLD, RM, and DRM had full access to all the data in the study and take responsibility for the integrity of the data and the accuracy of the data analysis. DRM had final responsibility for the decision to submit for publication.

\section{Authors' contributions}

Study concept and design: RLD, MCC, KTW, SMW, DRM

Data acquisition: RLD, TW, DRM

Analysis and interpretation of data: AKM, GT, MCC, SMW, DRM

Manuscript preparation: AKM, GT, SMW, DRM

Critical review: AKM, GT, RLD, MCC, TW, KTW, SMW, DRM

\section{Acknowledgements}

We recognize our colleagues in the Hospital de Occidente, Honduras Ministry of Health, and Central America Medical Outreach (CAMO), with special thanks to Lesby

Castellanos, Carmen Ramos, Kathy Tschiegg, and Dr. Lia Suazo. We acknowledge the contributions of Dr. Enrique Martinez (Hospital Evangelico, Honduras) and Dr. Michael

Pawlita (DKFZ). 


\section{ABSTRACT}

The primary cause of gastric cancer is chronic infection with Helicobacter pylori $(H$.

pylori), particularly the high-risk genotype $\operatorname{cag} A$, and risk modification by human genetic variants. We studied 94 variants in 54 genes for association with gastric cancer, including rs2302615 in ornithine decarboxylase (ODC1), which may affect response to chemoprevention with the ODC inhibitor, eflornithine (difluoromethylornithine; DFMO). Our population-based, case-control study included 1366 individuals (664 gastric cancer cases and 702 controls) from Western Honduras, a high incidence region of Latin America. CagA seropositivity was strongly associated with cancer $(\mathrm{OR}=3.6 ; 95 \% \mathrm{Cl}$ : 2.6, 5.1). The $O D C 1$ variant $r s 2302615$ was associated with gastric cancer $(O R=1.36 ; p$ $=0.018$ ) in a model adjusted for age, sex, and CagA serostatus. Two additional single nucleotide polymorphisms (SNPs) in CASP1 (rs530537) and TLR4 (rs1927914) genes were also associated with gastric cancer. The ODC1 SNP association with gastric cancer was stronger in individuals who carried the TT genotype at the associating TLR4 polymorphism, rs1927914 $\left(\mathrm{OR}=1.77 ; \mathrm{p}=1.85 \times 10^{-3}\right)$. In conclusion, the $O D C 1$ variant, rs2302615, is associated with gastric cancer and supports chemoprevention trials with DFMO, particularly in individuals homozygous for the risk allele, C, at rs2302615. 
medRxiv preprint doi: https://doi.org/10.1101/2021.04.13.21254467; this version posted April 15, 2021. The copyright holder for this preprint (which was not certified by peer review) is the author/funder, who has granted medRxiv a license to display the preprint in perpetuity.

All rights reserved. No reuse allowed without permission.

\section{INTRODUCTION}

Gastric adenocarcinoma is the third leading cause of global cancer mortality, and the leading infection-associated cancer, driven by chronic infection with Helicobacter pylori. $(1,2)$ There is also remarkable geographic variability of gastric cancer $(G C)$ with respect to both incidence(3) and mortality.(4) Latin America has among the highest GC incidence rates in the world. There is an excess burden in the mountainous regions along the Pacific littoral as compared with coastal populations, even though the two regions have high endemic H. pylori infection; this has been termed the "Latin American altitude enigma".(3) Altitude appears to be a surrogate for the clustering in the mountain villages of high-risk interactions between host genetic and $H$. pylori genetic factors(5), with modulation by dietary and environment factors.(6)

In the United States, GC represents a marked cancer disparity, with an excess burden among minorities. The GC incidence is approximately doubled among nonwhites, including Hispanics.(7) Notably, immigrants from high GC incidence areas are atrisk. Those who emigrate from high-to-low incidence regions maintain the risk of their nation of origin, most likely due to their 'importing' their host and $H$. pylori genetic risks.(8)

The gastric carcinogenesis pathway is a multifactorial process that progresses from pre-malignant to malignant phenotypes through several histopathology stages: normal mucosa, chronic gastritis, atrophic gastritis, intestinal metaplasia, dysplasia, and adenocarcinoma.(9) Progression is driven by host genetics and $H$. pylori virulence and oncogenic factors, as well as dietary and environmental influences. H. pylori accounts for much of the attributable risk with cagA being the principal $H$. pylori risk genotype, and the CagA protein as the dominant virulence factor for gastric adenocarcinoma.(10-14)

Human germline mutations are thought to be important drivers in up to $10-15 \%$ of incident GC cases.(15) An elevated risk of GC has been associated with gene 
medRxiv preprint doi: https://doi.org/10.1101/2021.04.13.21254467; this version posted April 15, 2021. The copyright holder for this preprint (which was not certified by peer review) is the author/funder, who has granted medRxiv a license to display the preprint in perpetuity.

All rights reserved. No reuse allowed without permission.

polymorphisms including those in the inflammation pathway, such as genes encoding IL$1 \beta$, TNF- $\alpha$, and IL-10.(12, 16, 17) Additionally, associations between GC and variants in PSCA and MUC1 (18-20), and at a locus that includes PRKAA1 and PTGER4 $(20,21)$ have been detected in genome-wide association studies of GC in Asian populations. Few studies have explicitly examined the host genetic basis for GC in Latin American populations.(22) The interaction of genetic variants in both the host and $H$. pylori affect disease progression and may explain some of the geographic variation in GC risk, yet the specific human loci and their relationship to disease risk remain poorly understood. $(5,23,24)$

Knowledge of human cancer risk loci may identify at-risk populations and has potential for targeting chemoprevention. For example, in colorectal cancer with the adenoma precursor lesion, there are potential targeted treatments for chemoprevention such as those based on ornithine decarboxylase (ODC1) gene variants. In humans, an ODC1 variant, rs2302615, has been associated with adenoma risk, as well as an augmented chemoprevention response to alpha-difluoromethylornithine (DFMO). Patients with the CC genotype have a higher risk of colon adenomas, yet are more responsive to DFMO and sulindac. $(25,26)$ This ODC1 SNP is located in intron 1, a region known to affect $O D C 1$ transcription (25), but no data exists on the relationship of this polymorphism and human GC. However, this gene may also be relevant to GC as myeloid-cell specific deletion of the Odc1 gene in mice results in enhanced host immune response to $H$. pylori and diminished bacterial load in the stomach.(27) $H$. pylori-induced ODC activity is associated with macrophage apoptosis. $(28,29)$ In addition, studies have identified variants in ODC pathway genes that associate with GC.(30) Based on these prior studies, we hypothesized that $O D C 1$, and rs2302615 in particular, which associates with transcription, will affect the risk for GC. 
medRxiv preprint doi: https://doi.org/10.1101/2021.04.13.21254467; this version posted April 15, 2021. The copyright holder for this preprint (which was not certified by peer review) is the author/funder, who has granted medRxiv a license to display the preprint in perpetuity.

All rights reserved. No reuse allowed without permission.

In addition to evaluating the ODC1 variant described above, we analyzed 93 candidate single nucleotide polymorphisms (SNPs) in 53 genes potentially linked to GC based on prior association studies of gastric cancer and gastritis.(31-37) These markers have largely been studied in European and East Asian populations, with few studies in high risk Latin American populations. They fall into classes related to mechanisms of inflammation, immunity, $H$. pylori colonization, and oxidative stress (38-42), as well as many of the dietary and environmental markers associated with disease, but some do not have a clear mechanism. $(6,43)$

Our study aimed at determining patterns of genetic association in the mountainous regions of Western Honduras, where the GC incidence is among the highest in Latin America.(3) We assessed if the genotypes of the ODC1 SNP, rs2302615, were associated with GC in the high-risk Western Honduran population and in what context they were the most strongly associated. We also examined the other SNPs with known significance in GC and asked if putative association of the other SNPs was modified by the ODC1 genotype risk.

\section{RESULTS}

Of the 1500 individuals in this population-based, case-control study in Honduras, complete genetic data were available for 1366 participants. The mean ages of GC cases and controls were 63.8 and 53.6 years, respectively. Males comprised $70 \%(n=468)$ and $50 \%(n=350)$ of cases and controls, respectively. H. pylori and CagA seropositive cases were determined by a multiplex serology (see Methods). Overall, a high H. pylori prevalence was confirmed, detected in $90.5 \%$ and $88.2 \%$ of cases and controls, respectively. $H$. pylori CagA seropositivity was $87 \%$ and $73.6 \%$ in cases and controls, respectively, and strongly associated with GC in the unadjusted analysis (Odds Ratio, $\mathrm{OR}=3.59 ; 95 \% \mathrm{Cl} 2.56,5.11 ; \mathrm{p}=6.0 \times 10^{-14} ;$ Table 1$)$. 
medRxiv preprint doi: https://doi.org/10.1101/2021.04.13.21254467; this version posted April 15, 2021. The copyright holder for this preprint (which was not certified by peer review) is the author/funder, who has granted medRxiv a license to display the preprint in perpetuity. All rights reserved. No reuse allowed without permission.

Of the 94 selected SNPs, one SNP, rs4072037, was out of Hardy-Weinberg equilibrium ( $p<1.0 \times 10^{-16}$ for both cases and controls), indicating a likely genotyping error, and was excluded from the analyses. In addition, 11 SNPs were excluded with a minor allele frequency of less than 0.05 (Table S1, Table S2). Linkage Disequilibrium (LD) was detected between 20 SNP pairs in which 4 SNPs appeared in two pairs. A total of 28 SNPs were excluded, resulting in 66 SNPs for the final analysis (Table S3, Figure S1). The Benjamini-Hochberg FDR test with an FDR level of 0.1 determined a multiple testing threshold of $p=0.021$.

Cases were associated with ODC1 genotype considered as cancer risk (CC) or protective $(\mathrm{CT} / \mathrm{TT})$ based on the colon cancer literature using a chi-square analysis $(\mathrm{p}=$ 0.021).(44-46) In the unadjusted logistic regression model, the ODC1 SNP was associated with $\mathrm{GC}(\mathrm{OR}=1.21,95 \% \mathrm{Cl} 1.14,1.80 ; \mathrm{p}=0.027)$. In the model adjusted for age, sex, and CagA status, and FDR corrected for multiple testing, the ODC1 SNP was significantly associated with $\mathrm{GC}(\mathrm{OR}=1.36,95 \% \mathrm{Cl} 1.05,1.76 ; \mathrm{p}=0.018)($ Table 2 , Table S4).

Of the remaining 65 SNPs, initial unadjusted association analyses identified seven SNPs with risk or protective associations with GC where the major allele was used as the reference. In an additive regression model, GC was associated with rs35686 in the ghrelin and obestatin prepropeptide $(G H R L)$ gene, $(p=0.015)$, rs4129009 in tolllike receptor-10 $(T L R 10)(\mathrm{p}=0.014)$, prostate stem cell antigen $(P S C A)(\mathrm{p}=0.009)$, rs1927914 in toll-like receptor-4 (TLR4) $(\mathrm{p}=0.0004)$, and rs530537 in caspase-1 (CASP1) $(p=0.0007)$ (Table 2). Lastly, two SNPs, rs1056836 and rs1800440, in cytochrome P450 family 1 subfamily B member 1 (CYP1B1) were both associated with GC ( $p=0.001$ and $p=0.011$, respectively) (Table 2). The two CYP1B1 SNPs are not in LD $\left(R^{2}=0.034\right)$. In the models adjusted for age, sex, and bacterial CagA serostatus, 
only the SNPs in the TLR4 and CASP1 genes remained significant: $T L R 4(\mathrm{OR}=1.23 ; \mathrm{p}$ $=0.021)$ and $C A S P 1(\mathrm{OR}=1.23 ; \mathrm{p}=0.019)$.

In the final model with the three SNPs (ODC1, TLR4, CASP1) and adjusted for age, sex, and CagA serostatus, only the ODC1 SNP remained significant $(\mathrm{OR}=1.35 ; \mathrm{p}$ $=0.021)$, as well as age (OR 1.03, 95\% Cl 1.02, 1.04), sex (OR 2.65, 95\% Cl 1.91, 3.71), and CagA (OR 3.16, 95\% Cl, 1.93, 5.26). SNPs in TLR4 $(\mathrm{OR}=1.04 ; \mathrm{p}=0.30)$ and CASP1 $(\mathrm{OR}=1.02 ; \mathrm{p}=0.27)$ were not significant in the final model. There were no detected interactions between CASP1 and ODC1 (OR = 1.02; $\mathrm{p}=0.68)$ nor TLR4 and ODC1 $(\mathrm{OR}=1.04 ; \mathrm{p}=0.52)$. However, noting the effects of the TLR4 and CASP1 loci on $O D C 1$-related risk, we performed stratified analyses on the subsets of these two loci to assess how $O D C 1$ risk changes among strata. The effect of the $O D C 1$ genotype in the TLR4 TT subset alone $\left(n=563 ; O R=1.77 ; p=1.85 \times 10^{-3}\right)$ was significant, and with a larger effect size.

We also performed a stratified analysis restricting to the 1095 high-risk individuals who were CagA seropositive. Unadjusted analysis of these individuals were significant $(p<0.021)$ for the previously identified SNPs: $r s 1927914 / T L R 4(O R=1.34 ; p$ $=0.005), r s 1056836 / C Y P 1 B 1(O R=0.77 ; p=0.008)$, and $r s 2302615 / O D C 1(O R=1.35$; $\mathrm{p}=0.020)$. One additional SNP was identified in this high-risk cohort, rs4129009/TLR10, also passed the FDR threshold $(O R=0.717 ; p=0.018)$. The ORs were of similar magnitude and size in the unadjusted and adjusted models for all individuals (Table 2, Table 3).

\section{DISCUSSION}

We found significant associations of the ODC1 rs2302615 SNP, TLR4 rs1927914, CASP1 rs530537, and H. pylori CagA seropositivity with gastric adenocarcinoma in the rural high incidence region of Western Honduras. The ODC1 
medRxiv preprint doi: https://doi.org/10.1101/2021.04.13.21254467; this version posted April 15, 2021. The copyright holder for this preprint (which was not certified by peer review) is the author/funder, who has granted medRxiv a license to display the preprint in perpetuity.

All rights reserved. No reuse allowed without permission.

rs2302615 SNP is of particular interest as it remained significant when adjusted for the other SNPs and is an actionable SNP previously seen in colorectal cancer.(25) CagA is the principal $H$. pylori oncogenic virulence factor for GC, and in studies with adjustment for CagA serostatus, the effect sizes of the human genetic variants are usually significantly reduced, $(47,48)$; however, in our study the effect sizes for H. pylori remained robust for the ODC1 rs2302615 SNP following adjustment.

This is the first study, to our knowledge, demonstrating an association of an ODC1 SNP with GC. Notably, in a Korean cohort investigation, other variants in this pathway were associated with GC, indicating that ODC may play a role in risk even if specific genes and variants differ by population.(21) In conjunction with the colon cancer and gut microbiota literature, these results indicate a broader role for this pathway in gastrointestinal cancers. $(21,49-54)$ ODC is the rate-limiting enzyme for polyamine biosynthesis that contributes to the pathogenesis of colitis and associated carcinogenesis by impairing M1 macrophage responses for antitumor immunity in a mouse model.(55) Loss of ODC in myeloid cells enhances host defense against $H$. pylori.(27) Similarly, EGFR signaling in macrophages has a significant role in colitisassociated carcinogenesis.(56) ODC generates polyamines that regulate the host immune response and is associated with DNA damage, due to the release of hydrogen peroxide by the back conversion of spermine to spermidine by spermine oxidase (SMOX), as spermidine and SMOX are associated with beta-catenin activation in gastric epithelial cells.(57-59) Both our current study and the colon cancer study by Zell et al. report odds ratios of similar magnitude for $O D C 1$ with the T allele as the reference allele: $\mathrm{GC}(\mathrm{OR}=1.36)$ and colorectal cancer survival $(\mathrm{OR}=2.02) \cdot(45)$

In addition to the ODC1 SNP, rs2302615, we found that SNPs in the CASP1 and TLR4 genes were also associated with GC. The ODC1 SNP genotype is highly significant when including covariates age, sex, CagA serostatus, and stronger in the 
medRxiv preprint doi: https://doi.org/10.1101/2021.04.13.21254467; this version posted April 15, 2021. The copyright holder for this preprint (which was not certified by peer review) is the author/funder, who has granted medRxiv a license to display the preprint in perpetuity. All rights reserved. No reuse allowed without permission.

TLR4 TT subset. CASP1 encodes for caspase-1, which is an important inflammasome mediator that cleaves precursors of key inflammatory cytokines into active proteins, including the interleukin-1 family and the pyroptosis inducer gasdermin D. (60-62) These $C A S P$-1-dependent processes are critical in mediating an immune response that effectively dampens $H$. pylori infection and regulates the host immune response, especially to cagA-positive isolates.(63-68) TLR4 encodes the Toll-like receptor-4, which elicits a strong inflammatory immune response by binding lipopolysaccharide ligands on the surface of Gram-negative bacteria and triggering the MyD88 inflammatory pathway to activate monocytes and neutrophils to clear infections.(69) Variants of TLR4 have been associated with risk for chronic $H$. pylori infection in multiple studies in humans and mice.(70-72) They have also been implicated in carcinogenesis and metastasis and associated with a broad range of pathology, including recurrent spontaneous miscarriage and diabetic retinopathy in type-2 diabetes. $(73,74)$

Our findings may have potential GC chemoprevention implications. The administration of DFMO to patients in high-risk GC regions where pre-malignant lesions are prevalent may be warranted. This concept is supported by findings that DFMO significantly attenuates GC development in $H$. pylori-infected Mongolian gerbils. $(57,58)$ If the mechanism is similar to colon cancer, DFMO could be used for chemoprevention in humans with a precision medicine approach and focused on those with the higher risk CC ODC1 genotype, and especially in those who also have the TLR4 TT genotype, which was observed in $40.6 \%$ of the patients in our population. The genotype CC ODC1 and diplotype ODC1 CC/ TLR4 TT have a prevalence of $29.5 \%$ and $11.5 \%$, respectively, in the Honduras population.

In summary, our findings suggest that $O D C 1$ genotyping and $H$. pylori CagA seropositivity is significantly associated with gastric adenocarcinoma in Western Honduras. In addition, its association and potential therapeutic efficacy may be 
medRxiv preprint doi: https://doi.org/10.1101/2021.04.13.21254467; this version posted April 15, 2021. The copyright holder for this preprint (which was not certified by peer review) is the author/funder, who has granted medRxiv a license to display the preprint in perpetuity. All rights reserved. No reuse allowed without permission.

enhanced in those with the TT genotype at TLR4 rs1927914. Nonetheless, replication studies in diverse populations will be necessary to confirm possible generalizability. If confirmed by independent studies, this finding will be an important innovation in guiding a precision based intervention for GC in this and perhaps other high-risk populations and potentially reducing the GC mortality in the high incidence regions of Latin America and Asia.

\section{Subjects and Methods}

Study population

We conducted a population-based, case control study in the mountainous region of west-central Honduras. The population is of Hispanic-Mestizo ethnicity and this region has among the highest incidence rates in the western hemisphere, with a high prevalence of chronic $H$. pylori infection (80-90\%).(75) Incident GC cases were enrolled prospectively from the two district hospitals (Santa Rosa de Copán, Siguatepeque) that serve the mountainous rural areas of west-central Honduras. The diagnosis of GC was based on endoscopic appearance and confirmatory histopathology. Household interviews were conducted for the randomly selected controls in the villages in the region. A novel multiplex serology determined $H$. pylori and CagA serostatus, the dominant bacterial risk genotype for $\mathrm{GC} .(37,76,77)$ We focused on CagA, determined by antibodies to this oncoprotein, as the optimal measure of cancer risk with bacterial chronic infection, given the high $H$. pylori prevalence in the region.

Of the 1500 people enrolled in the case-control study, complete genotyping results were available for 1366 subjects (664 cases, 702 controls). Overall, $89.3 \%$ and $80.2 \%$ of subjects were seropositive for $H$. pylori infection and CagA, respectively, as outlined in Table 1. SNPs were chosen in loci in distinct cancer risk pathways (Table S1), including the ODC1 SNP (rs2302615) data that was analyzed both as one of the 94 
medRxiv preprint doi: https://doi.org/10.1101/2021.04.13.21254467; this version posted April 15, 2021. The copyright holder for this preprint (which was not certified by peer review) is the author/funder, who has granted medRxiv a license to display the preprint in perpetuity. All rights reserved. No reuse allowed without permission.

SNPs and as a covariate, since it has postulated protective effects (CT/TT). The selected SNPs are biased towards coding regions with 17 non-coding SNPs in high LD with both coding and noncoding SNPs $\left(R^{2}>0.8\right)$ (Table S2, Table S3). Genetic variant analysis

Human DNA was isolated from whole blood samples with the Qiagen Puregene ${ }^{\circledR}$ kit and genotyped on the Sequenom ${ }^{\circledR}$ platform. The ODC1 rs2302615 SNP was determined by TaqMan assay (Thermo Fisher). Some SNPs were also included as they previously associated with putative disease processes in colon cancer.(78) The 94 hypothesis-driven SNPs fell into four different categories, corresponding to functional SNPs in the GC literature: inflammation and immunity, oncogenic environmental factors, and nutrition (Table S1). (49-54)

Statistical analyses

Using PLINK (version 1.9), 12 of the 94 selected SNPs were removed due to Hardy-Weinberg equilibrium or a minor allele frequency less than 0.05 (Table S1, Table S2).(79) Allele frequencies were within the expected ranges, based on the Latin American populations in the 1000 genomes databases.(80) False Discovery Rate (FDR) was used to calculate a threshold for individual SNP significance using the BenjaminiHochberg test with a FDR level of 0.1 for all tests. In tests of significance across multiple models, trend tests were used including basic allelic test, the Cochran-Armitage trend test, dominant and recessive models and a genotypic test. Additionally, linkage disequilibrium (LD) was characterized in PLINK and Haploview (version 4.2) among the SNPs regardless of case-control designation to determine the number of independent tests for the FDR threshold.(81) A total of 66 SNPs were considered in the final analysis as linkage disequilibrium (LD) $\left(R^{2} \geq 0.9\right)$ was detected between 20 SNP pairs in which 4 appeared in two pairs, with 16 total SNPs excluded (Table S3, Figure S1). 
medRxiv preprint doi: https://doi.org/10.1101/2021.04.13.21254467; this version posted April 15, 2021. The copyright holder for this preprint (which was not certified by peer review) is the author/funder, who has granted medRxiv a license to display the preprint in perpetuity. All rights reserved. No reuse allowed without permission.

Association tests and unadjusted analyses of the final 66 SNPs were performed in PLINK (version 1.9).(79) Analyses of the resulting SNPs significant at $p<0.1$ were analyzed in adjusted models for covariates age, sex, CagA serostatus, and ODC1 genotype were performed in $\mathrm{R}$ (version 3.6.3). In all cases except one, the referent allele was the major allele; the exception was $O D C 1$ where the prior work on colon cancer indicted that the CC genotype was the risk genotype, but in our population, $\mathrm{C}$ was the major allele. Therefore, we used the T allele as the referent for this SNP to assess the risk conferred by the CC genotype in parallel with the prior literature. Select covariates were included based on summary statistics in current data and prior studies. Covariates age and sex was expected to influence genetic effects as age positively associates with GC incidence.(82) GC incidence is also notably higher in males, revealing the possible impact of sex hormones on development of gastric disease.(83-85) CagA serostatus was included in all adjusted models as individuals exposed to cagA-positive bacteria associate with increased risk of GC severity. $(47,48)$ Stratified analyses were restricted to the 1095 individuals carrying cagA-positive bacteria to evaluate the effect of CagA using a univariate analysis. $O D C 1$ status was grouped into genotypes associated with putative risk (CC) or protection (CT/TT) based on previous studies. $(25,45)$ Logistic regression was used to estimate $\mathrm{OR}$, adjusted for age, sex, CagA serostatus, and $O D C 1$ genotype. SNPs significant individually were also tested for interactions and assessed in stratified analyses. 
medRxiv preprint doi: https://doi.org/10.1101/2021.04.13.21254467; this version posted April 15, 2021. The copyright holder for this preprint (which was not certified by peer review) is the author/funder, who has granted medRxiv a license to display the preprint in perpetuity.

\section{REFERENCES}

1. Bray F, Ferlay J, Soerjomataram I, Siegel RL, Torre LA, Jemal A. Global cancer statistics 2018: GLOBOCAN estimates of incidence and mortality worldwide for 36 cancers in 185 countries. CA Cancer J Clin. 2018;68(6):394-424.

2. de Martel C, Georges D, Bray F, Ferlay J, Clifford GM. Global burden of cancer attributable to infections in 2018: a worldwide incidence analysis. Lancet Glob Health. 2020;8(2):e180-e90.

3. Torres J, Correa P, Ferreccio C, Hernandez-Suarez G, Herrero R, CavazzaPorro M, et al. Gastric cancer incidence and mortality is associated with altitude in the mountainous regions of Pacific Latin America. Cancer Cause Control. 2013;24(2):24956.

4. Allemani C, Matsuda T, Di Carlo V, Harewood R, Matz M, Niksic M, et al. Global surveillance of trends in cancer survival 2000-14 (CONCORD-3): analysis of individual records for 37513025 patients diagnosed with one of 18 cancers from 322 populationbased registries in 71 countries. Lancet. 2018;391(10125):1023-75.

5. Kodaman N, Pazos A, Schneider BG, Piazuelo MB, Mera R, Sobota RS, et al. Human and Helicobacter pylori coevolution shapes the risk of gastric disease.

Proceedings of the National Academy of Sciences of the United States of America. 2014;111(4):1455-60.

6. Bonequi P, Meneses-Gonzalez F, Correa P, Rabkin CS, Camargo MC. Risk factors for gastric cancer in Latin America: a meta-analysis. Cancer Causes Control. 2013;24(2):217-31.

7. Miller KD, Goding Sauer A, Ortiz AP, Fedewa SA, Pinheiro PS, Tortolero-Luna G, et al. Cancer statistics for ispanics/Latinos, 2018. CA Cancer J Clin. 2018;68(6):42545 .

8. Pabla BS, Shah SC, Corral JE, Morgan DR. Increased incidence and mortality of gastric cancer in immigrant populations from high to low regions of incidence: $A$

systematic review and meta-analysis. Clin Gastroenterol Hepatol. 2020;18(2):347-59 e5.

9. Correa P. Helicobacter pylori and gastric cancer: state of the art. Cancer Epidemiol Biomarkers Prev. 1996;5(6):477-81.

10. Venerito M, Vasapolli R, Rokkas T, Malfertheiner P. Gastric cancer:

epidemiology, prevention, and therapy. Helicobacter. 2018;23 Suppl 1:e12518.

11. Burucoa C, Axon A. Epidemiology of Helicobacter pylori infection. Helicobacter. 2017;22 Suppl 1.

12. El-Omar EM, Carrington M, Chow WH, McColl KE, Bream JH, Young HA, et al. Interleukin-1 polymorphisms associated with increased risk of gastric cancer. Nature. 2000;404(6776):398-402.

13. Tavera G, Morgan DR, Williams SM. Tipping the scale toward gastric disease: A ost-pathogen genomic mMismatch? Curr Genet Med Rep. 2018;6(4):199-207.

14. Kupfer SS. Gaining ground in the genetics of gastric cancer. Gastroenterology. 2017;152(5):926-8.

15. Blaser MJ, Perez-Perez GI, Kleanthous H, Cover TL, Peek RM, Chyou PH, et al. Infection with Helicobacter pylori strains possessing cagA is associated with an increased risk of developing adenocarcinoma of the stomach. Cancer Res. 1995;55(10):2111-5.

16. El-Omar EM, Rabkin CS, Gammon MD, Vaughan TL, Risch HA, Schoenberg JB, et al. Increased risk of noncardia gastric cancer associated with proinflammatory cytokine gene polymorphisms. Gastroenterology. 2003;124(5):1193-201. 
medRxiv preprint doi: https://doi.org/10.1101/2021.04.13.21254467; this version posted April 15, 2021. The copyright holder for this preprint (which was not certified by peer review) is the author/funder, who has granted medRxiv a license to display the preprint in perpetuity.

17. Tian J, Liu G, Zuo C, Liu C, He W, Chen H. Genetic polymorphisms and gastric cancer risk: a comprehensive review synopsis from meta-analysis and genome-wide association studies. Cancer Biol Med. 2019;16(2):361-89.

18. Abnet CC, Freedman ND, Hu N, Wang Z, Yu K, Shu XO, et al. A shared susceptibility locus in PLCE1 at 10q23 for gastric adenocarcinoma and esophageal squamous cell carcinoma. Nature genetics. 2010;42(9):764-7.

19. Study Group of Millennium Genome Project for C, Sakamoto H, Yoshimura K, Saeki N, Katai H, Shimoda T, et al. Genetic variation in PSCA is associated with susceptibility to diffuse-type gastric cancer. Nature genetics. 2008;40(6):730-40.

20. Shi Y, Hu Z, Wu C, Dai J, Li H, Dong J, et al. A genome-wide association study identifies new susceptibility loci for non-cardia gastric cancer at $3 q 13.31$ and 5p13.1. Nature genetics. 2011;43(12):1215-8.

21. Song HR, Kim HN, Kweon SS, Choi JS, Shim HJ, Cho SH, et al. Genetic variations in the PRKAA1 and ZBTB20 genes and gastric cancer susceptibility in a Korean population. Mol Carcinog. 2013;52 Suppl 1:E155-60.

22. Gonzalez-Hormazabal P, Retamales-Ortega R, Musleh M, Bustamante M, Stambuk J, Pisano R, et al. Polymorphisms PSCA rs2294008, IL-4 rs2243250 and MUC1 rs4072037 are associated with gastric cancer in a high risk population. Mol Biol Rep. 2020;47(11):9239-43.

23. Snaith A, El-Omar EM. Helicobacter pylori: host genetics and disease outcomes. Expert Rev Gastroenterol Hepatol. 2008;2(4):577-85.

24. Kodaman N, Sobota RS, Mera R, Schneider BG, Williams SM. Disrupted humanpathogen co-evolution: a model for disease. Front Genet. 2014;5:290.

25. Zell JA, McLaren CE, Chen WP, Thompson PA, Gerner EW, Meyskens FL. Ornithine decarboxylase-1 polymorphism, chemoprevention with eflornithine and sulindac, and outcomes among colorectal adenoma patients. J Natl Cancer Inst. 2010;102(19):1513-6.

26. Martinez ME, O'Brien TG, Fultz KE, Babbar N, Yerushalmi H, Qu N, et al. Pronounced reduction in adenoma recurrence associated with aspirin use and a polymorphism in the ornithine decarboxylase gene. Proc Natl Acad Sci U S A. 2003;100(13):7859-64.

27. Hardbower DM, Asim M, Luis PB, Singh K, Barry DP, Yang C, et al. Ornithine decarboxylase regulates $\mathrm{M} 1$ macrophage activation and mucosal inflammation via histone modifications. Proceedings of the National Academy of Sciences of the United States of America. 2017;114(5):E751-E60.

28. Cheng Y, Chaturvedi R, Asim M, Bussiere FI, Scholz A, Xu H, et al. Helicobacter pylori-induced macrophage apoptosis requires activation of ornithine decarboxylase by c-Myc. J Biol Chem. 2005;280(23):22492-6.

29. Asim M, Chaturvedi R, Hoge S, Lewis ND, Singh K, Barry DP, et al. Helicobacter pylori induces ERK-dependent formation of a phospho-c-Fos c-Jun activator protein-1 complex that causes apoptosis in macrophages. J Biol Chem. 2010;285(26):20343-57. 30. Cho LY, Yang JJ, Ko KP, Ma SH, Shin A, Choi BY, et al. Gene polymorphisms in the ornithine decarboxylase-polyamine pathway modify gastric cancer risk by interaction with isoflavone concentrations. Gastric Cancer. 2015;18(3):495-503.

31. Morgan DR, Dominguez RL, Keku TO, Heidt PE, Martin CF, Galanko JA, et al. Gastric cancer and the high combination prevalence of host cytokine genotypes and Helicobacter pylori in Honduras. Clin Gastroenterol Hepatol. 2006;4(9):1103-11.

32. Cai H, Ye F, Michel A, Murphy G, Sasazuki S, Taylor PR, et al. Helicobacter pylori blood biomarker for gastric cancer risk in East Asia. Int $\mathrm{J}$ Epidemiol. 2016;45(3):774-81. 
medRxiv preprint doi: https://doi.org/10.1101/2021.04.13.21254467; this version posted April 15, 2021. The copyright holder for this preprint (which was not certified by peer review) is the author/funder, who has granted medRxiv a license to display the preprint in perpetuity.

All rights reserved. No reuse allowed without permission.

33. Parsonnet J, Friedman GD, Orentreich N, Vogelman H. Risk for gastric cancer in people with CagA positive or CagA negative Helicobacter pylori infection. Gut. 1997;40(3):297-301.

34. Gao L, Weck MN, Michel A, Pawlita M, Brenner H. Association between chronic atrophic gastritis and serum antibodies to 15 Helicobacter pylori proteins measured by multiplex serology. Cancer Res. 2009;69(7):2973-80.

35. Weck MN, Gao L, Brenner H. Helicobacter pylori infection and chronic atrophic gastritis: associations according to severity of disease. Epidemiology. 2009;20(4):569-

74.

36. Epplein M, Zheng W, Xiang YB, Peek RM, Jr., Li H, Correa P, et al. Prospective study of Helicobacter pylori biomarkers for gastric cancer risk among Chinese men. Cancer Epidemiol Biomarkers Prev. 2012;21(12):2185-92.

37. Michel A, Waterboer T, Kist M, Pawlita M. Helicobacter pylori multiplex serology. Helicobacter. 2009;14(6):525-35.

38. Hardbower DM, Peek RM, Jr., Wilson KT. At the Bench: Helicobacter pylori, dysregulated host responses, DNA damage, and gastric cancer. J Leukoc Biol. 2014;96(2):201-12.

39. Zambon CF, Basso D, Navaglia F, Belluco C, Falda A, Fogar P, et al. Pro- and anti-inflammatory cytokines gene polymorphisms and Helicobacter pylori infection: interactions influence outcome. Cytokine. 2005;29(4):141-52.

40. Hardbower DM, de Sablet T, Chaturvedi R, Wilson KT. Chronic inflammation and oxidative stress: the smoking gun for Helicobacter pylori-induced gastric cancer? Gut Microbes. 2013;4(6):475-81.

41. Kim JJ, Tao H, Carloni E, Leung WK, Graham DY, Sepulveda AR. Helicobacter pylori impairs DNA mismatch repair in gastric epithelial cells. Gastroenterology. 2002;123(2):542-53.

42. Kavermann H, Burns BP, Angermuller K, Odenbreit S, Fischer W, Melchers K, et al. Identification and characterization of Helicobacter pylori genes essential for gastric colonization. J Exp Med. 2003;197(7):813-22.

43. Fox JG, Wang TC. Inflammation, atrophy, and gastric cancer. J Clin Invest. 2007;117(1):60-9.

44. Mondaca S, Yaeger R. Colorectal cancer genomics and designing rational trials. Ann Transl Med. 2018;6(9):159.

45. Zell JA, Ziogas A, Ignatenko N, Honda J, Qu N, Bobbs AS, et al. Associations of a polymorphism in the ornithine decarboxylase gene with colorectal cancer survival. Clin Cancer Res. 2009;15(19):6208-16.

46. Jensen $\mathrm{KH}$, Izarzugaza JMG, Juncker AS, Hansen RB, Hansen TF, Timshel P, et al. Analysis of a gene panel for targeted sequencing of colorectal cancer samples. Oncotarget. 2018;9(10):9043-60.

47. Park JY, Forman D, Waskito LA, Yamaoka Y, Crabtree JE. Epidemiology of Helicobacter pylori and CagA-positive infections and global variations in gastric cancer. Toxins (Basel). 2018;10(4).

48. Pormohammad A, Ghotaslou R, Leylabadlo HE, Nasiri MJ, Dabiri H, Hashemi A. Risk of gastric cancer in association with Helicobacter pylori different virulence factors: A systematic review and meta-analysis. Microb Pathog. 2018;118:214-9.

49. Jakszyn P, Bingham S, Pera G, Agudo A, Luben R, Welch A, et al. Endogenous versus exogenous exposure to $\mathrm{N}$-nitroso compounds and gastric cancer risk in the European Prospective Investigation into Cancer and Nutrition (EPIC-EURGAST) study. Carcinogenesis. 2006;27(7):1497-501. 
medRxiv preprint doi: https://doi.org/10.1101/2021.04.13.21254467; this version posted April 15, 2021. The copyright holder for this preprint (which was not certified by peer review) is the author/funder, who has granted medRxiv a license to display the preprint in perpetuity.

All rights reserved. No reuse allowed without permission.

50. Haley KP, Gaddy JA. Nutrition and Helicobacter pylori: host diet and nutritional immunity influence bacterial virulence and disease outcome. Gastroenterol Res Pract. 2016;2016:3019362.

51. La Torre G, Chiaradia G, Gianfagna F, De Lauretis A, Boccia S, Mannocci A, et al. Smoking status and gastric cancer risk: an updated meta-analysis of case-control studies published in the past ten years. Tumori. 2009;95(1):13-22.

52. Bonder MJ, Kurilshikov A, Tigchelaar EF, Mujagic Z, Imhann F, Vila AV, et al. The effect of host genetics on the gut microbiome. Nature genetics. 2016;48(11):140712.

53. Kurilshikov A, Wijmenga C, Fu J, Zhernakova A. Host Genetics and Gut Microbiome: Challenges and Perspectives. Trends Immunol. 2017;38(9):633-47.

54. Kolde R, Franzosa EA, Rahnavard G, Hall AB, Vlamakis $H$, Stevens $C$, et al. Host genetic variation and its microbiome interactions within the Human Microbiome Project. Genome medicine. 2018;10(1):6.

55. Singh K, Coburn LA, Asim M, Barry DP, Allaman MM, Shi C, et al. Ornithine decarboxylase in macrophages exacerbates colitis and promotes colitis-associated colon carcinogenesis by impairing M1 immune responses. Cancer Res.

2018;78(15):4303-15.

56. Hardbower DM, Coburn LA, Asim M, Singh K, Sierra JC, Barry DP, et al. EGFRmediated macrophage activation promotes colitis-associated tumorigenesis. Oncogene. 2017;36(27):3807-19.

57. Sierra JC, Suarez G, Piazuelo MB, Luis PB, Baker DR, Romero-Gallo J, et al. alpha-Difluoromethylornithine reduces gastric carcinogenesis by causing mutations in Helicobacter pylori cagY. Proceedings of the National Academy of Sciences of the United States of America. 2019;116(11):5077-85.

58. Chaturvedi R, de Sablet T, Asim M, Piazuelo MB, Barry DP, Verriere TG, et al. Increased Helicobacter pylori-associated gastric cancer risk in the Andean region of Colombia is mediated by spermine oxidase. Oncogene. 2015;34(26):3429-40.

59. Sierra JC, Piazuelo MB, Luis PB, Barry DP, Allaman MM, Asim M, et al. Spermine oxidase mediates Helicobacter pylori-induced gastric inflammation, DNA damage, and carcinogenic signaling. Oncogene. 2020;39(22):4465-74.

60. Castano-Rodriguez N, Kaakoush NO, Goh KL, Fock KM, Mitchell HM. The NODlike receptor signalling pathway in Helicobacter pylori infection and related gastric cancer: a case-control study and gene expression analyses. PLoS One. 2014;9(6):e98899.

61. Li X, Liu S, Luo J, Liu A, Tang S, Liu S, et al. Helicobacter pylori induces IL-1beta and IL-18 production in human monocytic cell line through activation of NLRP3 inflammasome via ROS signaling pathway. Pathog Dis. 2015;73(4).

62. Hitzler I, Sayi A, Kohler E, Engler DB, Koch KN, Hardt WD, et al. Caspase-1 has both proinflammatory and regulatory properties in Helicobacter infections, which are differentially mediated by its substrates IL-1beta and IL-18. J Immunol. 2012;188(8):3594-602.

63. Koch KN, Hartung ML, Urban S, Kyburz A, Bahlmann AS, Lind J, et al. Helicobacter urease-induced activation of the TLR2/NLRP3/IL-18 axis protects against asthma. The Journal of clinical investigation. 2015;125(8):3297-302.

64. Yang JC, Yang HC, Shun CT, Wang TH, Chien CT, Kao JY. Catechins and sialic acid attenuate Helicobacter pylori-triggered epithelial caspase-1 activity and eradicate Helicobacter pylori infection. Evid Based Complement Alternat Med. 2013;2013:248585. 65. Koch KN, Muller A. Helicobacter pylori activates the TLR2/NLRP3/caspase-1/IL18 axis to induce regulatory T-cells, establish persistent infection and promote tolerance to allergens. Gut Microbes. 2015;6(6):382-7. 
medRxiv preprint doi: https://doi.org/10.1101/2021.04.13.21254467; this version posted April 15, 2021. The copyright holder for this preprint (which was not certified by peer review) is the author/funder, who has granted medRxiv a license to display the preprint in perpetuity.

All rights reserved. No reuse allowed without permission.

66. Wilson KT, Crabtree JE. Immunology of Helicobacter pylori: insights into the failure of the immune response and perspectives on vaccine studies. Gastroenterology. 2007;133(1):288-308.

67. Peek RM, Jr., Miller GG, Tham KT, Perez-Perez GI, Zhao X, Atherton JC, et al. Heightened inflammatory response and cytokine expression in vivo to cagA+ Helicobacter pylori strains. Lab Invest. 1995;73(6):760-70.

68. Rolig AS, Cech C, Ahler E, Carter JE, Ottemann KM. The degree of Helicobacter pylori-triggered inflammation is manipulated by preinfection host microbiota. Infect Immun. 2013;81(5):1382-9.

69. Gong Y, Tao L, Jing L, Liu D, Hu S, Liu W, et al. Association of TLR4 and Treg in Helicobacter pylori colonization and inflammation in mice. PLoS One. 2016;11(2):e0149629.

70. Smith SM. Role of Toll-like receptors in Helicobacter pylori infection and immunity. World J Gastrointest Pathophysiol. 2014;5(3):133-46.

71. Su B, Ceponis PJ, Lebel S, Huynh H, Sherman PM. Helicobacter pylori activates Toll-like receptor 4 expression in gastrointestinal epithelial cells. Infect Immun. 2003;71(6):3496-502.

72. Wang TR, Peng JC, Qiao YQ, Zhu MM, Zhao D, Shen J, et al. Helicobacter pylori regulates TLR4 and TLR9 during gastric carcinogenesis. Int J Clin Exp Pathol. 2014;7(10):6950-5.

73. Takenaka R, Yokota K, Ayada K, Mizuno M, Zhao Y, Fujinami Y, et al. Helicobacter pylori heat-shock protein 60 induces inflammatory responses through the Toll-like receptor-triggered pathway in cultured human gastric epithelial cells. Microbiology. 2004;150(Pt 12):3913-22.

74. Jin J, Lin F, Liao S, Bao Q, Ni L. Effects of SNPs (CYP1B1*2 G355T, CYP1B1*3 C4326G, and CYP2E1*5 G-1293C), smoking, and drinking on susceptibility to laryngeal cancer among Han Chinese. PloS one. 2014;9(10):e106580.

75. Dominguez RL, Crockett SD, Lund JL, Suazo LP, Heidt P, Martin C, et al. Gastric cancer incidence estimation in a resource-limited nation: use of endoscopy registry methodology. Cancer Causes Control. 2013;24(2):233-9.

76. Waterboer T, Sehr P, Michael KM, Franceschi S, Nieland JD, Joos TO, et al. Multiplex human papillomavirus serology based on in situ-purified glutathione stransferase fusion proteins. Clin Chem. 2005;51(10):1845-53.

77. Butt J, Blot WJ, Shrubsole MJ, Waterboer T, Pawlita M, Epplein M. Differences in antibody levels to $H$. pylori virulence factors VacA and CagA among African Americans and whites in the Southeast USA. Cancer Causes Control. 2020;31(6):601-6.

78. Teschendorff AE, Menon U, Gentry-Maharaj A, Ramus SJ, Weisenberger DJ, Shen $\mathrm{H}$, et al. Age-dependent DNA methylation of genes that are suppressed in stem cells is a hallmark of cancer. Genome Res. 2010;20(4):440-6.

79. Purcell S, Neale B, Todd-Brown K, Thomas L, Ferreira MA, Bender D, et al. PLINK: a tool set for whole-genome association and population-based linkage analyses. Am J Hum Genet. 2007;81(3):559-75.

80. Genomes Project C, Auton A, Brooks LD, Durbin RM, Garrison EP, Kang HM, et al. A global reference for human genetic variation. Nature. 2015;526(7571):68-74.

81. Barrett JC, Fry B, Maller J, Daly MJ. Haploview: analysis and visualization of LD and haplotype maps. Bioinformatics. 2005;21(2):263-5.

82. Rowland M, Daly L, Vaughan M, Higgins A, Bourke B, Drumm B. Age-specific incidence of Helicobacter pylori. Gastroenterology. 2006;130(1):65-72; quiz 211.

83. de Martel C, Parsonnet J. Helicobacter pylori infection and gender: a metaanalysis of population-based prevalence surveys. Dig Dis Sci. 2006;51(12):2292-301. 
medRxiv preprint doi: https://doi.org/10.1101/2021.04.13.21254467; this version posted April 15, 2021. The copyright holder for this preprint (which was not certified by peer review) is the author/funder, who has granted medRxiv a license to display the preprint in perpetuity. All rights reserved. No reuse allowed without permission.

84. Replogle ML, Glaser SL, Hiatt RA, Parsonnet J. Biologic sex as a risk factor for Helicobacter pylori infection in healthy young adults. Am J Epidemiol. 1995;142(8):85663.

85. Camargo MC, Goto Y, Zabaleta J, Morgan DR, Correa P, Rabkin CS. Sex hormones, hormonal interventions, and gastric cancer risk: a meta-analysis. Cancer Epidemiol Biomarkers Prev. 2012;21(1):20-38. 
Table 1. Selected characteristics of gastric cancer cases and population controls

\begin{tabular}{|c|c|c|c|c|}
\hline Characteristics & $\begin{array}{l}\text { Overall } \\
\mathrm{N}=1366\end{array}$ & $\begin{array}{c}\text { Gastric Cancer Cases } \\
\qquad \mathrm{N}=664\end{array}$ & $\begin{array}{l}\text { Healthy Control Population } \\
\qquad \mathrm{N}=702\end{array}$ & P-value \\
\hline Age & & & & $<2 \times 10-16$ \\
\hline Mean in years (SD)* & $58.5(16.1)$ & $63.78(13.7)$ & $53.52(16.5)$ & \\
\hline Sex, n (\%) & & & & $1.34 \times 10-14$ \\
\hline Male & $818(60 \%)$ & $468(70 \%)$ & $350(50 \%)$ & \\
\hline Female & $548(40 \%)$ & $196(30 \%)$ & $352(50 \%)$ & \\
\hline H. pylori serostatus, n (\%) & & & & 0.009 \\
\hline Positive & $1220(89.3 \%)$ & $601(90.5 \%)$ & $619(88.2 \%)$ & \\
\hline Negative & $78(5.7 \%)$ & $26(3.9)$ & $52(7.4 \%)$ & \\
\hline Missing & $68(4.98 \%)$ & $37(5.6 \%)$ & $31(4.4 \%)$ & \\
\hline CagA serostatus, n (\%) & & & & $6.0 \times 10-14$ \\
\hline Positive & $1095(80.2 \%)$ & $578(87.0 \%)$ & $517(73.6 \%)$ & \\
\hline Negative & 202 (14.8\%) & $48(7.2 \%)$ & $154(21.9 \%)$ & \\
\hline Missing & $69(5.05 \%)$ & $38(5.7 \%)$ & $31(4.4 \%)$ & \\
\hline
\end{tabular}

Notes: *Standard deviation (SD) 
Table 2. Associations of single nucleotide polymorphisms (SNPs) with gastric cancer risk

\begin{tabular}{|c|c|c|c|c|c|c|c|c|c|}
\hline Chromosome & SNP & Gene & $\begin{array}{l}\text { Major } \\
\text { allele }\end{array}$ & $\begin{array}{l}\text { Minor } \\
\text { allele }\end{array}$ & MAF & $\begin{array}{l}\text { Unadjusted OR } \\
(95 \% \mathrm{Cl})\end{array}$ & $\begin{array}{c}\text { p-value } \\
\text { (unadjusted) }\end{array}$ & $\begin{array}{l}\text { Adjusted }{ }^{\star} \text { OR } \\
(95 \% \mathrm{Cl})\end{array}$ & $\begin{array}{c}\text { Adjusted } \\
\text { p-value }\end{array}$ \\
\hline 2 & rs2302615 & $O D C 1$ & C & $\mathrm{T}^{\mathrm{a}}$ & 0.264 & $1.21(1.14,1.80)$ & 0.027 & $1.36(1.05,1.76)$ & 0.018 \\
\hline 9 & rs1927914 & TLR4 & $\mathrm{T}^{\mathrm{a}}$ & $\mathrm{C}$ & 0.365 & $1.33(1.13,1.54)$ & 0.0004 & $1.23(1.03,1.47)$ & 0.021 \\
\hline 11 & rs530537 & CASP1 & $A^{a}$ & $\mathrm{G}$ & 0.499 & $1.30(1.11,1.51)$ & 0.0007 & $1.23(1.03,1.45)$ & 0.019 \\
\hline 2 & rs1800440 & CYP1B1 & $A^{a}$ & $\mathrm{G}$ & 0.094 & $0.71(0.55,0.93)$ & 0.011 & $0.74(0.55,0.98)$ & 0.04 \\
\hline 3 & rs35683 & GHRL & $\mathrm{C}^{\mathrm{a}}$ & A & 0.276 & $0.81(0.690 .96)$ & 0.015 & $0.85(0.71,1.03)$ & 0.096 \\
\hline
\end{tabular}

Notes:

- a referent allele

- * Adjusted for age, sex, and cagA serostatus, with respective ORs age (OR 1.03, 95\% Cl 1.02, 1.04), sex (OR 2.65, 95\% Cl 1.91,

3.71), and CagA (OR 3.16, 95\% Cl, 1.93, 5.26).

- Odds ratio (OR) only included if $p<0.10$ and bolded SNPs pass FDR cut off 
Table 3. Associations of single nucleotide polymorphisms (SNPs) with gastric cancer risk among CagA-seropositive cases and controls

\begin{tabular}{|c|c|c|c|c|}
\hline Chromosome & SNP & Gene & $\begin{array}{l}\text { Adjusted OR }(95 \% \\
\text { Cl })^{*}\end{array}$ & p-value \\
\hline 1 & rs1801131 & MTHFR & & 0.835 \\
\hline 1 & rs1801133 & MTHFR & & 0.428 \\
\hline 1 & rs1846522 & FAF1 & & 0.36 \\
\hline 1 & rs1137101 & LEPR & & 0.95 \\
\hline 1 & rs5845 & SELENOF & & 0.65 \\
\hline 1 & rs1800871 & IL 10 & & 0.566 \\
\hline 1 & rs1800896 & IL10 & & 0.543 \\
\hline 2 & rs2302615 & $O D C 1$ & $1.36(1.05,1.75)$ & 0.02 \\
\hline 2 & rs1800440 & CYPTB1 & $0.77(0.54,1.02)$ & 0.069 \\
\hline 2 & rs1056836 & CYPTB1 & $0.77(0.57,0.95)$ & 0.008 \\
\hline 2 & rs10197208 & GKN3P & & 0.655 \\
\hline 2 & rs1143634 & $I L 1 B$ & & 0.982 \\
\hline 2 & rs1143627 & $I L 1 B$ & & 0.257 \\
\hline 2 & rs16944 & $I L 1 B$ & & 0.206 \\
\hline 2 & rs419598 & IL1RN & & 0.913 \\
\hline 2 & rs1063728 & $R P R M$ & & 0.873 \\
\hline 2 & rs61261057 & UGT1A10 & & 0.969 \\
\hline 2 & rs17868323 & UGT1A10 & & 0.291 \\
\hline 2 & rs11692021 & UGT1A10 & $0.54(0.69,1.03)$ & 0.096 \\
\hline 3 & rs35683 & GHRL & $0.81(0.67,0.97)$ & 0.024 \\
\hline 3 & rs9841504 & ZBTB20 & & 0.452 \\
\hline 4 & rs4129009 & TLR10 & $0.72(0.54,0.94)$ & 0.018 \\
\hline 4 & rs4543123 & TLR1 & $0.81(0.65,1.00)$ & 0.053 \\
\hline 4 & rs5743604 & TLR1 & $0.15(0.97,1.36)$ & 0.099 \\
\hline 4 & rs6815814 & TLR1 & & 0.389 \\
\hline 4 & rs4588 & $G C$ & & 0.364 \\
\hline 4 & rs7041 & $G C$ & & 0.596 \\
\hline 4 & rs4073 & CXCL8 & & 0.47 \\
\hline 5 & rs13361707 & PRKAA1 & & 0.095 \\
\hline 5 & rs7579 & $C C D C 152$ & & 0.687 \\
\hline 5 & rs3877899 & $C C D C 152$ & & 0.751 \\
\hline 6 & rs3020314 & $E S R 1$ & & 0.492 \\
\hline 6 & rs4880 & SOD2 & & 0.344 \\
\hline 7 & rs2066853 & $A H R$ & & 0.284 \\
\hline 7 & rs1800795 & IL6 & & 0.235 \\
\hline 8 & rs5030839 & NAT1 & & 0.572 \\
\hline 8 & rs15561 & NAT1 & & 0.756 \\
\hline 8 & rs1041983 & NAT2 & & 0.178 \\
\hline 8 & rs1799929 & NAT2 & & 0.186 \\
\hline 8 & rs1799930 & NAT2 & & 0.464 \\
\hline 8 & rs1799931 & CYP2C9 & & 0.293 \\
\hline
\end{tabular}


medRxiv preprint doi: https://doi.org/10.1101/2021.04.13.21254467; this version posted April 15, 2021. The copyright holder for this preprint (which was not certified by peer review) is the author/funder, who has granted medRxiv a license to display the preprint in perpetuity.

All rights reserved. No reuse allowed without permission.

\begin{tabular}{|c|c|c|c|c|}
\hline 8 & rs2294008 & $\overline{P S C A}$ & & 0.336 \\
\hline 9 & rs1927914 & TLR4 & $1.34(1.08,1.54)$ & 0.005 \\
\hline 9 & rs505922 & $A B O$ & & 0.277 \\
\hline 10 & rs10508902 & ARHGAP22 & & 0.924 \\
\hline 10 & rs2031920 & CYP2E1 & & 0.658 \\
\hline 11 & rs12794714 & CYPR1 & & 0.937 \\
\hline 11 & rs2060793 & CYPR1 & & 0.533 \\
\hline 11 & rs12800438 & NADSYN1 & $1.19(1.01,1.42)$ & 0.04 \\
\hline 11 & rs3829251 & NADSYN1 & $0.83(0.69,1.01)$ & 0.061 \\
\hline 11 & rs530537 & CASP1 & $1.20(1.01,1.43)$ & 0.034 \\
\hline 14 & rs4986938 & ESR2 & & 0.115 \\
\hline 14 & rs1950902 & MTHFD1 & & 0.51 \\
\hline 14 & rs2236225 & MTHFD1 & & 0.267 \\
\hline 15 & rs762551 & CYP1A2 & & 0.391 \\
\hline 16 & rs16260 & $\mathrm{CDH1}$ & $0.83(0.68,1.00)$ & 0.05 \\
\hline 17 & rs2297518 & NOS2 & & 0.588 \\
\hline 17 & rs7220169 & GAST & & 0.832 \\
\hline 19 & rs713041 & GPX4 & & 0.653 \\
\hline 19 & rs1800469 & B9D2 & & 0.953 \\
\hline 20 & rs13042395 & SLC52A3 & & 0.17 \\
\hline 20 & rs6116569 & SLC23A2 & & 0.286 \\
\hline 20 & rs6133175 & SLC23A2 & & 0.957 \\
\hline 20 & rs6053005 & SLC23A2 & & 0.197 \\
\hline 20 & rs17217119 & CYP24A1 & & 0.558 \\
\hline 21 & rs225439 & TFF3 & & 0.185 \\
\hline
\end{tabular}

${ }^{*}$ Odds ratio adjusted for age and sex are shown if $p<0.10$ (shown in bold) 